\title{
Growing habits? Delayed introduction of crop cultivation at marginal Neolithic wetland sites
}

\author{
Welmoed A. Out
}

Received: 10 October 2007/Accepted: 8 February 2008/Published online: 11 April 2008

(C) The Author(s) 2008

\begin{abstract}
This paper aims to gain a better understanding of the neolithisation process in the Netherlands after the arrival of the Linearbandkeramik Culture, focussing on local crop cultivation at Neolithic wetland sites of the Swifterbant Culture and Hazendonk Group. The debate of the past 30 years questions whether crop plants were cultivated locally in the exploitation area of wetland sites, or whether they were brought in from elsewhere. Which crop plants were introduced in the wetlands, when they were introduced and where they came from is investigated, based on published evidence from three main regions. The main crop plants introduced were emmer wheat and naked barley. Details of the introduction process are available only for the southern region. The complex discussion of botanical and non-botanical criteria supports local crop cultivation in most regions.
\end{abstract}

Keywords Neolithisation - Local crop cultivation · Swifterbant Culture · Hazendonk Group

\section{Introduction}

Knowledge of the neolithisation process of most parts of the Netherlands is still restricted. The process started with arrival of the fully Neolithic Linearbandkeramik (LBK) Culture in the very southeastern part of the Netherlands, an area characterised by loess soils at ca. 5300 cal B.c. (van

Communicated by K.-E. Behre.

W. A. Out $(\bowtie)$

Faculty of Archaeology, Leiden University, PO Box 9515, 2300 RA Leiden, The Netherlands

e-mail: w.a.out@arch.leidenuniv.nl
Gijn and Louwe Kooijmans 2005). The LBK Culture was followed by the Grossgartach Culture in 5000 B.C., the Blicquy Group and Rössen Culture in 4900 B.C. and the Michelsberg Culture in 4300 B.C. in the regions to the south and southeast of the Netherlands. The presence of these Neolithic neighbours resulted in a gradual neolithisation process, characterised by local pottery production in the Dutch wetlands in ca. 5000 B.c., introduction of domestic animals in ca. 4700 B.C. and introduction of crop plants even later. Suggestions for the date of introduction of crop plants are 4900 B.C. (Gehasse 1995, pp. 195-198), between ca. 4600 and 4000 B.C. (Brinkkemper et al. 1999, p. 82) and at least from 4100 B.c. onwards (Raemaekers 1999, p. 191). According to the first two hypotheses, the Rössen Culture played an important role in the introduction of crop plants, while the third hypothesis suggests that the Michelsberg Culture played a key role. People of both cultures cultivated a broad range of crops including cereals and pulses (Bakels 2003; Knörzer et al. 1999).

This study concerns Dutch wetland sites dating to 60003500 B.c., corresponding with the Late Mesolithic and the subsequent Swifterbant Culture and Hazendonk Group. The economy of the Swifterbant Culture and the Hazendonk Group was a broad-spectrum economy, based on hunting, gathering, fowling and fishing, supplemented by animal husbandry and crop cultivation in the course of time. The economy remained semi-agrarian until the Late Neolithic. The Dutch wetland sites are located in the Rhine/Meuse/IJssel river area, dominated by organic sediments (peat and clay). Three main regions can be discerned that consist of clusters of sites; the northern region, the southern region and the coastal region, while some additional sites occur outside these regions (Fig. 1). The sites are located on small patches of dry land, formed by river dunes, natural levees, coastal dunes and outcrops 


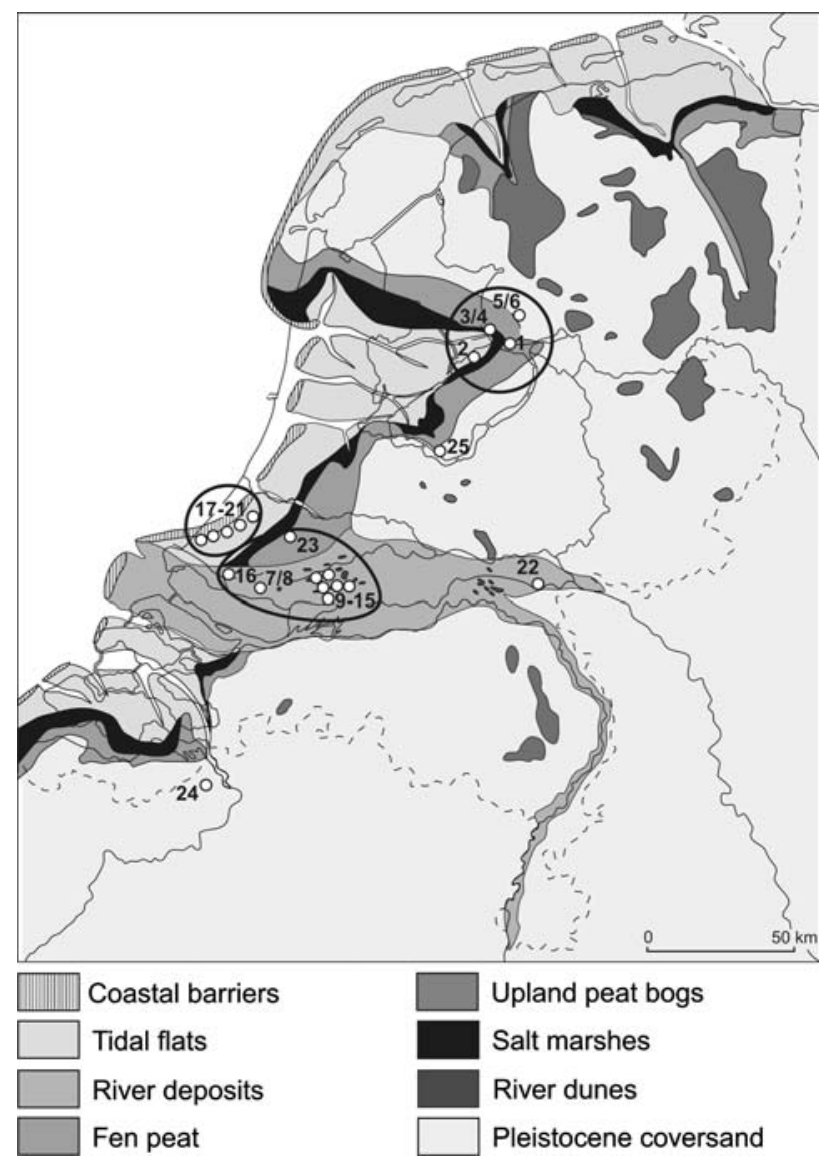

Fig. 1 The location of the main studied sites plotted on a palaeogeographic map of the Netherlands (4200 в.с.). Table 1 shows the names of the sites

of boulder clay. Preservation of organic material at the wetland sites is usually good since sedimentation under waterlogged conditions was continuous during prehistory.

Local crop cultivation at the Dutch wetland sites has been subject of debate since the seventies (Bakels 1981, 1986; Cappers and Raemaekers 2008; Casparie et al. 1977; Louwe Kooijmans 1993; Out 2008; van Zeist and Palfenier-Vegter 1981). On the one hand, the archaeobotanical finds indicate consumption of crop plants and possibly even local cultivation in the exploitation area of the sites. In particular the chaff remains of naked barley are a convincing argument for local crop cultivation for some authors, assuming that relative heavy chaff remains of freethreshing cereals preclude long-distance transport (e.g. Kubiak-Martens 2006; van Zeist and Palfenier-Vegter 1981). Local crop cultivation would moreover probably have been inferred if the same remains were found at sites located in the middle of dry terrain.

On the other hand, environmental conditions were far from optimal for crop cultivation, at least to our modernday view of arable farming. Most studied sites are located on patches of dry land with a surface area of only few hectares, surrounded by wetlands. The area that was not used for domestic activities and hence remained for fields was probably small. The area of dry terrain moreover decreased through time due to the rising water level, and seasonal flooding must have occurred frequently. Most sites were additionally located on sloping terrain, where deforestation would have caused a considerable risk of erosion.

The alternative to local crop cultivation is the importation of crop products from the Pleistocene sandy soils that surround the wetlands to the north, east and south (van Gijn and Louwe Kooijmans 2005). Subsistence data from these regions are however scarce since preservation of organic material is very poor. The hypothesis of importation of crop plants from the sandy soils assumes that people of the Swifterbant Culture and Hazendonk Group lived in the sandy regions during part of the year or that a part of their community was there. Importation of crop plants could additionally be the result of exchange with people of other, possibly fully Neolithic, cultural groups since the precise cultural identity of people living on the Pleistocene sandy soils is not clear.

The aim of this study is to give an overview of the archaeobotanical data to improve our understanding of the plant economy in relation to neolithisation. The first basic questions are which crop plants were cultivated, when were they introduced, and which culture played an important role in the introduction process. A further question is whether crops were cultivated locally in the exploitation area of Dutch wetland sites or whether crops where imported from elsewhere. In order to answer this fourth question, data from botanical remains, artefacts, features and site function are investigated.

\section{Materials and methods}

This study is based on literature research. Table 1 gives the main sites with their references. The original site investigation methods varied widely. Samples were usually collected from excavations, but occasionally only from cores, influencing the number, type and context of samples. Sample preparation usually included wet-sieving on sieves with a mesh-width down to $0.25 \mathrm{~mm}$. At most sites both waterlogged and carbonised material has been found.

\section{Results}

In the northern region, the main crop plants are emmer wheat (Triticum dicoccon) and naked barley (Hordeum vulgare var. nudum). At Urk-E4 only grains of einkorn (Triticum monococcum-type) were found. The einkorn 
Table 1 Information on the main studied sites and general information on the presence of crop plants ordered by region and time

\begin{tabular}{|c|c|c|c|c|c|}
\hline & Site & Age (cal в.с.) & Cereals & Other & References \\
\hline \multicolumn{6}{|c|}{ Northern region } \\
\hline 1 & Schokkerhaven-E170 & $3950-3700$ & + & & Gehasse (1995) \\
\hline 2 & Swifterbant-S3 & $4300-4000$ & + & & van Zeist and Palfenier-Vegter (1981) \\
\hline 3 & Urk-E4 late phases & $4200-3500$ & + & & Peters and Peeters (2001) \\
\hline 4 & Urk-E4 early phases & $7000-5050$ & $-(?)$ & & Peters and Peeters (2001) \\
\hline 5 & P14 later phases & $4400-4100$ & + & & Gehasse (1995) \\
\hline 6 & P14 early phases & $4900-4400$ & $-(?)$ & & Gehasse (1995) \\
\hline \multicolumn{6}{|c|}{ Southern region } \\
\hline 7 & Barendrecht 20.125 & $3660-3380$ & + & + & Meirsman and Moree (2006) \\
\hline 8 & Barendrecht 20.126 & $4050-3790$ & + & & Moree (2006) \\
\hline 9 & Hazendonk, early phases & $4020-3610$ & + & & Unpubl. data RMO/Leiden University \\
\hline 10 & Meerdonk & $4030-3910$ & + & & Verbruggen pers. comm. \\
\hline 11 & Rechthoeksdonk & $4240-3980$ & + & & Verbruggen pers. comm. \\
\hline 12 & Brandwijk-Kerkhof late phases & $4220-3630$ & + & + & Out (2008) \\
\hline 13 & Brandwijk-Kerkhof early phases & $4610-4370$ & $-(?)$ & & Out (2008) \\
\hline 14 & Hardinxveld-Giessendam Bruin & $5500-4550$ & - & & Bakels et al. (2001) \\
\hline 15 & Hardinxveld-Giessendam Polderweg & $5500-5000$ & - & & Bakels and van Beurden (2001) \\
\hline 16 & Rotterdam-Randstadrail & $5630-5380$ & $-(?)$ & & Guiran and Brinkkemper (2007) \\
\hline \multicolumn{6}{|c|}{ Coastal region } \\
\hline 17 & Schipluiden & $3630-3380$ & + & & Kubiak-Martens (2006) \\
\hline 18 & Wateringen & $3625-3400$ & + & & Raemaekers et al. (1997) \\
\hline 19 & Rijswijk-A4 & Middle Neolithic & + & & Unpubl. data Leiden University \\
\hline 20 & Sion (AHR-42) & $3640-3370$ & + & & Rieffe et al. (2006) \\
\hline 21 & Ypenburg & $3860-3435$ & + & & van Haaster (2001) \\
\hline \multicolumn{6}{|c|}{ Other sites } \\
\hline 22 & Nijmegen-Oosterhout & $3770-3530$ & + & & Out in Ball and van den Broeke $(2007,104)$ \\
\hline 23 & Bergschenhoek & $4300-4100$ & $-(?)$ & & Unpubl. data RMO/Leiden University \\
\hline 24 & Doel Deurganckdok-sector B & $4540-3960$ & + & & Bastiaens et al. (2005) \\
\hline 25 & Hoge Vaart & $6600-4150$ & - & & Brinkkemper et al. (1999) \\
\hline
\end{tabular}

The number in the first column corresponds with those in Fig. 1. Other $=$ other crops (see text) $+=$ present, $-=$ no indications for presence, $-(?)=$ no indications for presence, although the representativity of this result is questionable due to a small number of samples or remains, $\mathrm{RMO}=$ National Museum of Antiquities

grains may however also represent grains from the top of ears of emmer wheat (Nesbitt and Samuel 1996, p. 56). The small number of wheat grains identified down to species level from this site $(n=2)$ does not permit a final conclusion. A single bread wheat grain (Triticum cf. aestivum) was identified at Swifterbant-S3, but this may now be considered to represent a deformed grain of emmer wheat (cf. Braadbaart 2004, 2008).

In the northern region, cereals were present from ca. 4400 to 4100 в.с. onwards (Table 1), and the precise moment of cereal introduction is not known. For P14 (occupied until the Middle Bronze Age) it was suggested that cereals were present from 4900 B.C. onwards, partly based on ${ }^{14} \mathrm{C}$ dates obtained from food crusts (Gehasse 1995). However, most material from the relevant layer dates to 4400-4100 B.c. (cf. Brinkkemper et al. 1999) and in addition dating of food encrustation on pottery may have produced dates that are too early due to the possible presence of fish remains (reservoir effect; Ten Anscher personal communication). It is therefore assumed that the cereal finds of P14 are no older than 4400 в.c. Representative data on absence of crop plants in this region are available only from the site Hoge Vaart, located in the southwestern fringe of the northern region and used until ca. 4100 B.c. At this site active search for cereals and analysis of at least 44 samples resulted in strong indications of the absence of cereals, which on the one hand can be related to initial unavailability of crop plants and on the other hand to site function (Brinkkemper et al. 1999).

In the southern region there is again evidence for the regular presence of emmer wheat and naked barley. The combined evidence from Hardinxveld, Brandwijk-Kerkhof 
and Hazendonk indicates that cereals were absent before 4370 B.C. and were introduced from 4220 to 3940 B.C. onwards, or perhaps even earlier (Out 2008). Interestingly, some other crop plants are known from this region as well. Waterlogged seeds of opium poppy (Papaver somniferum ssp. setigerum) were found at the Swifterbant site Brandwijk-Kerkhof (Out 2008). Finds of opium poppy are known from three other Neolithic locations, but these are not dated precisely. Five carbonised peas (Pisum sativum) were found at the Hazendonk site Barendrecht 20.125 (Brinkkemper in Meirsman and Moree 2006), and represent the first Dutch find of peas younger than those from the Michelsberg Culture and older than the Iron Age (Bakels 2003; Dutch archaeobotanical database RADAR 2005). The uniqueness of the find may, however, be not related to introduction but to the small chances of carbonisation of peas during crop processing and food preparation and poor preservation in waterlogged state. The assemblages from both Brandwijk and Barendrecht 20.126 contained a few grains of einkorn-type. The single grain from Brandwijk is interpreted as emmer wheat, while as yet the number of cereal grains from Barendrecht is too small to make a final conclusion. The large variety of crop plants in the southern region points to active exchange and to a developed stage of the neolithisation process in the south.

In the coastal region finds of emmer wheat and naked barley date to the period 3900-3350 B.C. It is not possible to reconstruct the precise moment of the arrival of cereals in this region since older sites are not known. At Ypenburg, a single seed was identified as cf. Avena sp., which is considered to represent $A$. fatua that functioned as a weed in cereal fields (van Haaster 2001).

At the Belgian Swifterbant site Doel Deurganckdoksector B there is a find of a single grain of bread wheat/ macaroni wheat (Triticum aestivum/durum), interpreted as bread wheat (Bastiaens et al. 2005). At present the paucity of published archaeological data from the site and lack of other contemporaneous finds from this Belgian region hinders discussion of the significance of the species, the period of introduction and local crop cultivation (though see Crombé and Vanmontfort 2007).

Local crop cultivation has been investigated by analysis of both botanical and non-botanical site characteristics, such as cereal remains, potential arable weeds, indications of deforestation, querns, sickles, tillage marks and site function (Table 2). The evidence for the category of potential arable weeds includes both pollen and seeds. The degree of deforestation is based on information from pollen diagrams. The available pollen diagrams are used only to investigate presence of deforestation and cannot be used to conclude absence of deforestation, since deforestation may be invisible in pollen diagrams for various reasons. True absence of sickles and tillage marks is not always
Table 2 Evidence for local crop cultivation for the northern, southern and coastal region

\begin{tabular}{llll}
\hline & North & South & Coast \\
\hline Cereal grains & + & + & + \\
Cereal chaff & + & + & + \\
Cereal pollen & + & + & + \\
Potential arable weeds & + & + & + \\
Dominance of salt-tolerant crops & $+/-$ & - & $+/-$ \\
Deforestation & - & + & - \\
Querns & + & + & + \\
Sickles (cereal cutting tools) & - & - & + \\
Tillage marks & $?$ & - & - \\
Site function & $1 ?$ & $1,2, ?$ & $1, ?$ \\
\hline
\end{tabular}

$+=$ present, $-=$ no indications of presence, $+/-=$ present at some sites in the regions or during some phases, $?=$ debatable/unpublished finds. Site function: $1=$ base camps, 1 ? = base camps?, $2=$ extraction camps, ? = unknown

demonstrated since some excavation and research programs did not include such analysis.

\section{Discussion}

Comparison with the broader range of crop plants of relevant Neolithic cultures (Bakels 2003) shows that only a selection of available crop plants was introduced in the Dutch wetlands. The main crop plants at Dutch wetland sites of the Swifterbant Culture and Hazendonk Group are emmer wheat (T. dicoccon) and six-rowed naked barley (H. vulgare var. nudum), usually occurring together. This corresponds with other Northwest European Neolithic sites outside the loess area, where emmer and barley were the main crops of a relatively small crop spectrum as well. The importance of einkorn in the northern Netherlands remains to be assessed. Only in the southern region are opium poppy and pea present as well, possibly indicative of active exchange processes with southern groups.

The best data on the moment of introduction are available from the southern region, indicating absence of cereals until 4370 B.C., despite the presence of fully Neolithic communities in the regions to the south and east of the Netherlands from 5300 B.c. onwards. The data for this region thus show delayed introduction of crop plants (cf. Brinkkemper et al. 1999). The available data support the introduction of cereals after $4400 / 4300$ B.C. at the earliest in other regions as well, although precise data on the moment of introduction are less well known. Both the chronology and archaeological remains indicate that the Michelsberg Culture played an important role in the introduction of crop plants in the southern region (Out 2008; Raemaekers 1999), and archaeological finds suggest 
the same for the coastal region (Louwe Kooijmans 2007). For the northern region especially, the period and the instigators of the introduction of crop plants remain poorly known.

As discussed already, the crop assemblages of the Michelsberg Culture and the Swifterbant Culture show some differences, especially in respect of naked wheat (Triticum durum/turgidum). These differences may be related to differences in environmental conditions, cultivation practices and/or possibly cultural/ideological preferences. The shift may be better understood when more knowledge is available on the character and cultivation practices of communities living in the sandy upland regions, who form a missing link in the reconstruction of introduction of crop plants into the wetland regions.

\section{Local crop cultivation}

\section{Botanical finds}

In all three regions there are finds of cereal seeds, chaff and pollen, as well as seeds and pollen of potential arable weeds. Chaff of naked barley is found at all late fifth millennium and later sites where cereal macroremains were present, where preservation of organic material was good and where research methods focused on retrieval of small botanical macroremains, suggesting it was present at all comparable sites. This indicates either that cereals were cultivated locally at all these sites or that the chaff of naked barley should play a less important role in discussion of local crop cultivation (see "Introduction" and below). The botanical finds thus at least indicate the consumption of cereals, and may indicate cultivation. However, the finds of macroremains do not necessarily demonstrate local cultivation since the presence of cereal grains and chaff remains of both emmer wheat and naked barley can be explained by transport while still on the ear, partly for protection against fungi (Bakels 2000). Although transport on the ear seems uneconomic considering the volume, the harvesting of naked barley before final ripening and its storage on the ear could have been favoured for prevention of loss of grains during harvest and for optimal ripening (Cappers 2006, pp. 435-436). The presence of pollen can be explained both by importation of cereals on the ear and/or the presence of fields, since most cereal pollen is released during threshing rather than during flowering (Robinson and Hubbard 1977). The presence of potential arable weeds has no meaning since these taxa may just represent local disturbance indicators. Many potential arable weeds were indeed present before introduction of crop plants (e.g. Bakels and van Beurden 2001; Bakels et al. 2001).
Interestingly, the ratio of emmer wheat to naked barley can be used to obtain information on local cultivation. At Swifterbant-S3 in the northern region, where minor marine influxes were occasionally present, naked barley dominates over emmer wheat (van Zeist and Palfenier-Vegter 1981). This suggests that crops were cultivated locally in the exploitation area of Swifterbant since naked barley tolerates marine conditions better than emmer wheat (Bottema et al. 1982, p. 139). At the other sites in this region the numbers of cereal grains are too small for representative ratio calculation. Interestingly, at a single site in the coastal region, Schipluiden, a shift from a brackish environment to a fresh-water environment corresponds with a shift from naked barley to emmer wheat (Kubiak-Martens 2006, p. 324). Similarly to the northern region, this dominance of naked barley during brackish conditions supports the idea of local cultivation. The ratio of emmer wheat and naked barley seems equal at two other coastal sites where the number of cereal grains allows analysis, which can be explained by local dominance of fresh-water conditions for at least one of the sites (Raemaekers et al. 1997). In the southern region, where marine influence is absent, emmer wheat is dominant, which does not per se prove local crop cultivation for this region, but which nevertheless demonstrates that naked barley was not automatically the dominant crop in all regions.

\section{Deforestation}

Only the pollen diagrams of Brandwijk and Hazendonk in the southern region show small-scale deforestation, which may be indicative of garden-like cultivation. For the northern region there are no indications of deforestation, but this has limited meaning since relevant pollen diagrams with small sample intervals are scarce. For the coastal region there are no indications of deforestation either, but this can be related to the natural vegetation of the dunes, consisting of open dune shrub vegetation. These shrubs produce only sparse pollen, reducing the possibility of detecting the presence of vegetation and occurrence of deforestation. The absence of indications of deforestation in the northern and coastal regions does not therefore support or reject the local presence of small arable fields.

\section{Querns and sickles}

Querns have been found in all regions, but these only indicate consumption. Sickles (flint artefacts with cereal gloss in a longitudinal direction caused by cereal cutting) until now have only been found in the coastal region (van Gijn et al. 2006). The flint assemblages from Brandwijk and Hazendonk in the southern region did not include similar artefacts, although use-wear analysis of the flint 
from the Hazendonk does not exclude their presence either (van Gijn personal communication). In the northern region, there are no indications of the presence of sickles (van Gijn personal communication), although not all flint excavated has been investigated. The presence of sickles in the coastal region is a strong argument in support of local crop cultivation there. The absence of similar sickles in the other regions has limited significance, since people may have harvested their crops in ways other than by using sickles. In the Michelsberg Culture sickles are also scarce (Schreurs 2005, p. 308). If crop cultivation on Dutch wetlands was indeed introduced by the Michelsberg Culture, the cultivation methods and tool set of this culture may explain the absence of sickles at Swifterbant sites. The method of crop harvesting used in the Michelsberg Culture and Swifterbant Culture is poorly understood.

\section{Ard marks}

It was suggested that ard marks dating to the Swifterbant occupation phase were found at Urk-E4, which would represent the oldest ard marks in the Netherlands if not in northern Europe. These are questionable since the published features are not comparable to ard marks as known from the Funnel Beaker Culture and since the ard had presumably not been introduced in the Netherlands by the period concerned (Louwe Kooijmans 2006). It is actually unknown what kind of tillage marks to expect at sites of the Swifterbant Culture and Hazendonk Group since it is not known how these people prepared the soil for crop cultivation. This complicates the distinction between arable plots and general disturbance and reworking of the soil due to human activities. Relevant features showing traces of systematic soil digging have been excavated at Swifterbant-S4 in 2007 (Raemaekers, University of Groningen, personal communication), but these have not yet been published.

\section{Site function}

Site function gives additional indirect information on the possibilities for local crop cultivation. The function of sites in the northern region is poorly known due to the presence of palimpsests and the scarcity of organic material, but a function as base camp is suggested for several sites (Gehasse 1995; Peters and Peeters 2001; Raemaekers 1999). This site function is compatible with local crop cultivation. In the coastal region at least some sites also functioned as year-round occupied settlements (Louwe Kooijmans 2007). The Neolithic sites in the southern region probably functioned as extraction camps occupied repeatedly during various seasons, but the precise site function remains unclear (Louwe Kooijmans 2007), as do the resulting possibilities for crop cultivation.

\section{Conclusions}

Neolithisation of Dutch wetlands in ca. 4300 B.C. under the influence of the Michelsberg Culture resulted in the introduction of emmer wheat and naked barley as the main crops. Only in the south were some additional crops also introduced. For the northern and the coastal regions, it is necessary to collect more data to reconstruct the introduction process of crop plants. Furthermore, the precise process of crop plant introduction (just) before/at 4300 B.C. remains poorly understood.

The results allow conclusions on local cultivation in all regions despite the environmental conditions, although for each region a different type of evidence gives the decisive argument. For the northern region, the dominance of naked barley in relation to minor marine influence in the environment indicates local crop cultivation for at least one site. For the coastal region, the shift from naked barley to emmer in relation to environmental change, the finds of sickles and the site function strongly support local crop cultivation. For the southern region, the deforestation signal in the pollen diagrams suggests that crop plants may have been obtained by small-scale crop cultivation in the exploitation area (possibly on a scale of several square metres), while importation of cereals from the southern sandy soils remains an alternative. The positive indications for local crop cultivation in several Dutch wetland regions indicate that the presence of crop plants at sites of the Swifterbant Culture and the Hazendonk Group was the result of incorporation of cultivation in the subsistence from ca. 4300 B.c. onwards, and not just the result of frequent exchange with fully agrarian societies.

The difficulty in demonstrating local crop cultivation and the possibility of importation of cereals from elsewhere into marginal areas may also be relevant for other Middle Neolithic sites in Northwest Europe. Exchange of crop products could furthermore have been part of the very early stage of introduction of crop plants as part of initial neolithisation everywhere in Northwest Europe outside the loess area. There are two examples of comparable discussions. Firstly, availability of crop plants at the Swifterbant/Funnel Beaker site Hüde $\mathrm{I}$ is attested by scarce impressions of einkorn(-type) and barley. However, local cultivation is rejected because of environmental conditions and site function (Kampffmeyer 1991, p. 312). Reinvestigation of the relevant evidence may shed new light on this conclusion. Secondly, Richmond (1999, p. 34) rejects local cultivation during the Early Neolithic in Great Britain and suggests importation from other regions or from abroad instead. This argument seems to be strongly based on a post-processual interpretation that presumes a symbolic role of crop plants, while the archaeobotanical evidence shows that crop plants can also be explained as a common component of daily 
subsistence (Jones and Rowley-Conwy 2007). The author is not acquainted with other discussions based on similar evidence as obtained from the studied wetland sites. Usually investigators consider the suitability of the environment for local cultivation as less problematic, or ard marks support local cultivation (Tegtmeier 1993; Thrane 1989).

Acknowledgments This study is part of the project "From Hardinxveld to Noordhoorn: from forager to farmer" at the Leiden University, funded by NWO, Netherlands Organisation for Scientific Research. The Leiden University Fund (LUF) substantially supported the visit to the 14th IWGP symposium in Poland, 2007. I am very grateful to all Dutch and Belgian colleagues in archaeobotany since this literature study is based on their work. I would also like to thank O. Brinkkemper, K.-E. Behre, A. L. van Gijn, M. Verbruggen, D. C. M. Raemaekers, C. C. Bakels and L. P. Louwe Kooijmans.

Open Access This article is distributed under the terms of the Creative Commons Attribution Noncommercial License which permits any noncommercial use, distribution, and reproduction in any medium, provided the original author(s) and source are credited.

\section{References}

Bakels CC (1981) Neolithic plant remains from the Hazendonk, province of Zuid-Holland, The Netherlands. Z Archäol 15:141148

Bakels CC (1986) Akkerbouw in het moeras? Crop cultivation in the marshes? Rotterdam Papers 5:1-6

Bakels CC (2000) The Neolithization of the Netherlands: two ways, one result. In: Fairbairn AS (ed) Plants in Neolithic Britain and beyond. Oxbow, Oxford, pp 101-106

Bakels CC (2003) Die neolithischen Weizenarten des südlimburgischen Lössgebiets in den Niederlanden. In: Eckert JE, Eisenhauer U, Zimmermann A (eds) Archäologische Perspektiven. Leidorf, Rahden, pp 225-232

Bakels CC, van Beurden LM (2001) Archeobotanie. In: Louwe Kooijmans LP (ed) Hardinxveld-Giessendam Polderweg, vol 83. Rapportage Archeologische Monumentenzorg, pp 325-378

Bakels CC, van Beurden LM, Vernimmen TJJ (2001) Archeobotanie. In: Louwe Kooijmans LP (ed) Hardinxveld-Giessendam De Bruin, vol 88. Rapportage Archeologische Monumentenzorg, pp 369-434

Ball EAG, van den Broeke PW (2007) Opgravingen op 't Klumke te Nijmegen-Oosterhout. Boeren uit het Midden-Neolithicum, de IJzertijd en de Merovingische periode op een zandrug in de oostelijke Betuwe [Excavations at 't Klumke, NijmegenOosterhout. Middle Neolithic, Iron Age and Merovingian farmers on a sand ridge in the eastern Betuwe]. Archeol Ber Nijmegen 6

Bastiaens J, Deforce K, Klinck B, Meersschaert L, Verbruggen C, Vrydaghs L (2005) Palaeobotanical analyses. In: Crombé P (eds) The last hunter-gatherer-fishermen in sandy Flanders (NW Belgium). Academia Press, Ghent, pp 251-278

Bottema S, van Hoorn TC, Woldring H, Gremmen WHE (1982) An agricultural experiment in the unprotected salt marsh part II. Palaeohistoria 22:128-140

Braadbaart F (2004) Carbonization of peas and wheat-a window into the past. Ph.D. Thesis, Leiden University

Braadbaart F (2008) Carbonisation and morphological changes in modern dehusked and husked Triticum dicoccum and Triticum aestivum grains. Veget Hist Archaeobot 17:155-166
Brinkkemper O, Hogestijn W-J, Peeters H, Visser D, Whitton C (1999) The Early Neolithic site at Hoge Vaart, Almere, the Netherlands, with particular reference to non-diffusion of crop plants, and the significance of site function and sample location. Veget Hist Archaeobot 8:79-86

Cappers RTJ (2006) The reconstruction of agricultural practices in Ancient Egypt: an ethnoarchaeobotanical approach. Palaeohistoria 47/48:429-446

Cappers RTJ, Raemaekers DCM (2008) Cereal cultivation at Swifterbant? About being a Neolithic wetland farmer in the western part of the North European Plain. Curr Anthropol (in press)

Casparie WA, Mook-Kamps B, Palfenier-Vegter RM, Struijk PC, van Zeist W (1977) The palaeobotany of Swifterbant. Helinium 17:28-55

Crombé P, Vanmontfort B (2007) The neolithisation of the Scheldt basin in western Belgium. Proc Br Acad 144:263-285

Gehasse EF (1995) Ecologisch-archeologisch onderzoek van het Neolithicum en de Vroege Bronstijd in de Noordoostpolder met de nadruk op vindplaats P14 [Ecological-archaeological investigations of the Neolithic and the Early Bronze Age in the Noordoostpolder, with emphasis on the site P14]. Ph.D. Thesis, University of Amsterdam

Guiran AJ, Brinkkemper O in cooperation with Brinkhuizen DC, Klink A (2007) Rotterdam-Randstadrail: archeologisch onderzoek 1 Emplacement Centraal Station [Rotterdam-Randstadrail: archaeological investigation I Central Station Yard]. BOORrapporten 318

Jones G, Rowley-Conwy P (2007) On the importance of cereal cultivation in the British Neolithic. In: Colledge S, Conolly J (eds) The origins and spread of domestic plants in Southwest Asia and Europe. Left Coast Press, California, pp 391-419

Kampffmeyer U (1991) Die Keramik der Siedlung Hüde I am Dümmer. Untersuchungen zur Neolithisierung des nordwestdeutschen Flachlands. Ph.D. Thesis, Göttingen

Knörzer K-H, Gerlach R, Meurers-Balke J, Kalis AJ, Tegtmeier U, Becker WD, Jürgens A (1999) PflanzenSpuren. Archäobotanik im Rheinland: Agrarlandschaft und Nutzpflanzen in Wandel der Zeiten. Rheinland, Köln

Kubiak-Martens L (2006) Botanical remains and plant food subsistence. In: Louwe Kooijmans LP, Jongste PFB (eds) Schipluiden. A Neolithic settlement on the Dutch North Sea coast, c. 3500 cal BC. Analecta Praehistorica Leidensia 37/38:317-338

Louwe Kooijmans LP (1993) Wetland exploitation and upland relations of prehistoric communities in the Netherlands. In: Gardiner J (ed) Flatlands and wetlands: current themes in the East Anglian Archaeology. East Anglian Archaeology Report 50:71-116

Louwe Kooijmans LP (2006) Les débuts de la traction animale aux Pays-Bas et ses conséquences. In: Pétrequin P, Arbogast R-M, Pétrequin A-M, van Willigen S, Bailly M (eds) Premier chariots, premiers araires. La diffusion de la traction animale en Europe pendant les $4 \mathrm{e}$ et $3 \mathrm{e}$ millénaires avant notre ère, vol 29. CRA Monographies, pp 191-206

Louwe Kooijmans LP (2007) The gradual transition to farming in the Lower Rhine Basin. Proc Br Acad 144:287-309

Meirsman E, Moree JM in cooperation with Brinkhuizen DC, Brinkkemper O, van Rijn P, Zeiler JT (2006) Barendrecht Vrijenburg vindplaats 20.125. Een documenterend en waarderend onderzoek van archeologische sporen uit het Neolithicum door middel van een proefsleuf, Rotterdam [Barendrecht Vrijenburg vindplaats 20.125. Documentation and assessment of archaeological traces dating to the Neolithic by means of a test trench, Rotterdam]. BOORrapporten 264

Moree JM (2006) Barendrecht Gaatkensplas vindplaats 20.126. De waardering [Barendrecht Gaatkensplas site 20.126. The assessment]. BOORrapporten 303 
Nesbitt M, Samuel D (1996) From staple crop to extinction? The archaeology and history of the hulled wheats. In: Padulosi S, Hammer K, Heller J (eds) Hulled wheats. Proceedings of the first international workshop on hulled wheats, 21-22 July 1995, Castelvecchio Pascoli, Tuscany, Italy. International Plant Genetic Resources Institute, Rome, pp 41-100

Out WA (2008) Neolithisation at the site Brandwijk-Kerkhof, the Netherlands: natural vegetation, human impact and plant food subsistence. Veget Hist Archaeobot 17:25-39

Peters FJC, Peeters JHM (2001) De opgraving van de Mesolithische en Neolithische vindplaats Urk-E4 (Domineesweg, gemeente Urk) [The excavation of the Mesolithic and Neolithic settlement Urk-E4 (Domineesweg, mun. of Urk)]. Rapportage Archeologische Monumentenzorg 93

Raemaekers DCM (1999) The articulation of a 'New Neolithic'. The meaning of the Swifterbant Culture for the process of Neolithisation in the western part of the North European Plain (49003400 BC). Archaeological Studies Leiden University 3

Raemaekers DCM, Bakels CC, Beerenhout B, van Gijn AL, Hänninen K, Molenaar S, Paalman D, Verbruggen M, Vermeeren C (1997) Wateringen 4: a settlement of the Middle Neolithic Hazendonk 3 Group in the Dutch coastal area. Analecta Praehistorica Leidens 29:143-192

Richmond A (1999) Preferred economies. The nature of the subsistence base throughout mainland Britain during prehistory. BAR British Series 290

Rieffe EC, Kooistra LI, van Dijk J, van Beurden L (2006) AHR-I. In: Bulten EEB, Boonstra YM (eds) Archeologisch onderzoek in-en effluentleidingen afvalwaterzuivering Haagse Regio [Archaeological research waste water treatment pipes region The Hague].
Rapport Gemeente Den Haag, Afdeling Archeologie 0619:206259

Robinson M, Hubbard RNLB (1977) The transport of pollen in the bracts of hulled cereals. J Archaeol Sci 4:197-199

Schreurs J (2005) Het midden-Neolithicum in Zuid-Nederland. In: Deeben J, Drenth E, van Oorsouw M-F, Verhart L (eds) De steentijd van Nederland [Stone Age of the Netherlands]. Archeologie 11/12:301-332

Tegtmeier U (1993) Neolithische und bronzezeitliche Pflugspuren in Norddeutschland und den Niederlanden. Archäologische Berichte 3

Thrane H (1989) Danish plough-marks from the Neolithic and the Bronze Age. J Danish Archaeol 8:111-125

Van Gijn A, Louwe Kooijmans LP (2005) Early and Middle Neolithic: an introduction. In: Louwe Kooijmans LP, van den Broeke PW, Fokkens H, van Gijn A (eds) The prehistory of the Netherlands. Amsterdam University Press, Amsterdam, pp 203218

Van Gijn A, van Betuw V, Verbaas A, Wentink K (2006) Flint, procurement and use. In: Louwe Kooijmans LP, Jongste PFB (eds) Schipluiden. A Neolithic settlement on the Dutch North Sea coast, c. 3500 cal BC. Analecta Praehistorica Leidensia 37/ 38:129-166

Van Haaster H (2001) Archeobotanisch onderzoek naar de Neolithische bewoning op de vindplaats Rijswijk-Ypenburg [Archaeobotanical research concerning Neolithic occupation at the site Rijswijk-Ypenburg]. Biaxiaal 118

Van Zeist W, Palfenier-Vegter RM (1981) Seeds and fruits from the Swifterbant S3 site. Palaeohistoria 23:105-168 